Article

\title{
Expansion of Religious Pluralism in Korean Civil Society: A Case Study of Conscientious Objection in South Korea
}

\author{
Kwang Suk Yoo \\ Sociology, Kyung Hee University, Seoul 02447, Korea; ksyooii@khu.ac.kr \\ Received: 15 September 2018; Accepted: 22 October 2018; Published: 24 October 2018
}

\begin{abstract}
This paper analyzes a socio-cultural adaptation of the concept of religious pluralism, focusing on the matter of conscientious objection in Korean pluralistic situation. The issue of conscientious objection in Korea has extended from a religious and philosophical field to a political, diplomatic, and international problem, being influenced heavily by IRFR and UNHRC. Regardless of their numerical marginality, its social implication is revealed more clearly in recent decisions of local or higher courts and triggers another significant public discourse on how Korean civil society should expand a concept of pluralism to integrate them. The paper concludes that the concept of pluralism advances into an operational principle to prop up the civil society of Korea beyond the narrow concept of religious pluralism.
\end{abstract}

Keywords: Korean conscientious objection; pluralism in Korea; Korean religious market; sectarian pacifism; Korean civil society

\section{Introduction}

Conscientious objection based on religious belief makes the most significant discourse of how religious pluralism has been evolved in Korean public sphere. Especially the International Religious Freedom Reports (IRFR) issued by the U.S. government since 1999 has touched the imprisonment of conscientious objectors in Korea (IRFR 1998-2017), which caused both religious majority and minority to be engaged in the public discourse. The U.N. Human Rights Commission (UNHRC) has recommended Korean government introduce an alternative service for conscientious objectors many times since 1984. Although the IRFR and U.N. recommendations have no legal binding in Korea, their impact on Korea is never slight, socially and politically, because Korean government greatly depends on moral as well as political or diplomatic support of the U.S. and U.N. in a global society. In this context, Korean society is now under pressure to find a new way of relieving about 600 conscientious objectors who are imprisoned every year.

This paper analyzes a socio-cultural adaptation of the concept of religious pluralism, focusing on the matter of conscientious objection in Korean pluralistic situation, even if it is a universal principle of law binding global as well as Korean society. While such international norms as U.N. recommendations and the IRFR invokes religious freedom as a necessary condition of religious pluralism in a Christian or American way (Smith 2001, p. 153), both religious freedom and pluralism are new concepts that could not be made in Korean culture before the era of colonialism and modernization. From the first Korean constitution of 1948 on, the Korean legal system has obviously codified the separation of state and religion and guaranteed religious freedom as one of basic human rights, but those fundamental principles have not strictly been kept in real religious market. Similar to the monopolistic Confucianism of Chosun dynasty, which served as a political ideology to justify an absolute authority of the King, religious majorities such as Korean Protestantism and Buddhism have made a strong 
alliance with an absolute sovereign of national state during the period of modernization. This unequal structure of Korean religious market controlled by the existing religious and state powers in Korea encouraged the issue of conscientious objection, mostly Jehovah's Witnesses, to be closed within the conceptual framework of religious pluralism. In fact, Korean religious majorities focused mainly on attacking conscientious objectors' morality in the field of public discourse, not on the concept of conscientious objection itself, criticizing them for conspiring to avoid a compulsory military service in Korea. The national demographic census of Statistics Korea shows clearly that religious minorities occupy no more than $5 \%$ of the whole Korean population (K. Yoo 2015). An extreme imbalance of religious majority and minority remains rarely unchanged since 1985 when religious affiliation was initially asked (Statistics Korea 2017).

Under this socio-religious structure, it is reported that $92.5 \%$ of conscientious objectors worldwide are South Korean nationals (IRFR 1998-2017) ${ }^{1}$ and that 17,000 Jehovah's Witnesses have been imprisoned due to conscientious objection since 1950 in Korea (WOL 1930-2018) ${ }^{2}$. American Jehovah's Witnesses press the U.S. government to intervene in the issue of Korean conscientious objectors in terms of universal human rights. As a result, the issue of conscientious objection in Korea has extended from a religious and philosophical field to a political, diplomatic, and international problem, being influenced heavily by IRFR and UNHRC. Now the issue of conscientious objectors, regardless of their numerical marginality, triggers another significant public discourse on how Korean civil society should expand the concept of pluralism to integrate them.

In short, this paper focuses on a semantic expansion of pluralism from religious to secular field through tracking down the following questions: how religious majorities have comprehended religious minorities with conscientious objectors; how the latter have adapted itself to the established order supporting religious majorities; and how pluralism has changed into a functional principle inherent in Korean civil society. For a theoretical analysis, this article compares Jehovah's Witnesses with Seventh-Day Adventists in terms of religious market strategy in Korea, because the two minority groups have in common a tradition of conscientious objection based on Christian pacifism.

\section{Previous Studies}

A substantial amount of literature and empirical research exists on the issue of conscientious objection in Europe and America. Among them, the legal approach to religious minorities has become a dominant research trend, enough to overwhelm all other studies on historical, sociological, psychological, political, and economic relationship (Kaplan 1989; Richardson 1995; Peters 2000; Richardson and Introvigne 2001). Analysis and interpretation of changing court judgments, laws, acts, and constitutions are very useful for understanding various legal aspects concerning conscientious objection based on religious belief (Todd 1969; Barker 1982; Flowers 2002; Wah 2002; Richardson 2006). Another research paradigm of conscientious objection comes from a socio-historical approach in that religious pacifism is a historically important tradition to understand its various successors in Catholicism and Protestantism (Stevenson 1934; Sibley 1943; Brock 1968; Walters 1973; Moskos and Chambers 1993). These historical studies greatly contribute to a better understanding of conscientious objection based on religious belief. Robert C. Stevenson's article, "The Evolution of Pacifism," explains very well how Western society evolved from individualistic pacifism to collective or social pacifism in Christian tradition, ranging from early Christians such as Augustine or Ambrose to the present Quakers known as unique pacifists (Stevenson 1934, pp. 439-40). Likewise, Korean research on conscientious objection is mostly biased on the aspects of religious freedom, human rights, sociological theory of law, comparative study of law, and social ethics (S. Kim 2002; S.-S. Kang 2005; K.-D. Yoo 2005; Chin 2006), and there are only a few studies of Jehovah's Witnesses dealing limitedly with the issue

\footnotetext{
See 2013.

See yb14, p. 40.
} 
of conscientious objection (D. Kang 2006; Yoon 2007) unless many Christian theological articles are considered (D. Kim 2002; Shin 2004; K.-D. Yoo 2005).

This article pays more attention to a socio-cultural aspect of pluralistic religious market which has rarely been handled by previous studies. As Korean conscientious objectors belong to Jehovah's Witnesses without great exception, a multi-dimensional approach on them is necessarily required for a better understanding of their behavior as a religious minority. The unique pacifism of Jehovah's Witnesses cannot be understood without considering a historical, social, and cultural expansion of Christian pacifism. For example, while conscientious objectors belonging to Jehovah's Witnesses can be considered as a relatively radical wing of the American Christian tradition, they are apt to be regarded simply as a deviant cult which deny both legal justification of social order and historical tradition in Korean culture. While they can be good citizens that the legal system of society should protect in American civil society, they in Korea have been only criminals who cannot be tolerated socially, culturally, and legally. This multi-dimensional difference is not only a matter of the legal system, but also a matter of socio-cultural tradition to justify such legal system. In short, a new religiosity adhering to conscientious objection makes both religious and secular citizens internalize a pluralistic nature of civil society in a different way that imported religions such as Buddhism, Confucianism and Christianity grew into a religiously monopolistic majority throughout all Korean history. Given that there are no sociological studies on the social impact of Korean conscientious objectors (I. Kang 2003, 2005), it is meaningful to analyze drastic changes of recent judicial judgments surrounding conscientious objection in Korea rather than an unchanging principle of law or human rights. After all, the paper examines not only actual impact on Korean religious policy and pluralistic features of Korean religious market, but also how such international norm as International Covenant on Civil and Political Rights (ICCPR) and international recommendations issued by IRFR and U.N. Human Rights Commission (UNHRC) has influenced the qualitative progress of Korean civil society.

\section{A Historical Review of Korean Religious Regulation}

Korea has a long history of religious regulation since the era of Chosŏn Dynasty in the 14th century. From its beginning, the Dynasty officially announced and enforced its policy to promote Confucianism and oppress Buddhism because it had been founded on the Confucian political philosophy and bureaucratic system. In addition to Buddhism, it expelled almost all traditional religions out of the capital of Seoul and prohibited Buddhists and shamans from entering the capital of the Dynasty. Historically, this represented the start of religious regulations based on the national legal system in Korea, although it was only partially valid and very limited in the scope and extent of its regulations. As soon as the Japanese colonialists occupied Korea in 1910, religious regulation became more systematic and oppressive to make Korean religious organizations accommodating to Japanese colonialism. Various religious restrictions during the period of Japanese rule mainly focused on institutional religions that had organizational networks across the country. From the start of Japanese rule, Korean Buddhism and Catholicism were cooperative with the colonialist government, while Korean Protestantism and nationalistic new religious movements protested against it. Non-institutional and non-organizational religions such as shamanism or folk religions were regarded as superstition or pseudo-religion, and frequently punished as frauds. When shamans wanted to perform rituals, called kut, they had to shw a registration card issued by the Japanese government (Cho 1988, p. 324). Despite this Japanese restriction, fortune-telling practices were generally found across the nation. Murayama's 1933 survey sponsored by the Chosŏn Governor-General of Japan shows the widespread popularity of fortune-telling at that time (Murayama [1993] 2005). However, things changed after the 1945 Liberation. The legal structure of the religious market turned out to be even more favorable for major official religions such as Buddhism, Catholicism, and Protestantism. In 1948, the first constitution of the Republic of Korea announced in Article 12: (1) All people have the freedom of faith and conscience. (2) An establishment of religion is denied, and religion is separate from state. 
Article 12 remains even through the ninth amendment since 1948 without any serious revisions, but the idea of equality between religions is controlled by a legal system of hierarchy that consists of the constitution, laws, regulations, judicial decisions, customs, and so on. As the Korean government had the independent right to enact laws and regulations under the centralized presidential system, it was and is still the most influential actor of religious enactments except for the National Assembly in Korea. With regard to religious policy, it is noteworthy to recognize two Korean Presidents who had a remarkable impact on both the pattern of religious enactment and eventually the structure of the Korean religious market. Syng-man Rhee, who took power from 1948 to 1961, established very clearly a religious policy based on Christian political ideals. He, as an elder of a Korean Protestant church, pursued a relationship between religion and state to serve his Christian ideals. After the Korean War, his regime was heavily dependent on Protestantism because many American assistance groups such as Team Mission, World Vision, and Compassion Inc., actively engaged in various activities for reconstructing post-war Korean society, as well as supporting Korean Protestant churches (I. Kim 2003, p. 338). In 1952, President Rhee allowed Protestant chaplains to be assigned to all military bases, which was stipulated in 1961. This contributed to the basis of an evangelical movement to convert all military men into Protestants in the 1970s (I. Kim 2003, p. 379). Given that all male citizens have an obligatory military duty in Korea, such stipulations on the level of law or regulations caused to empty the ideal of religious freedom on the level of the constitution.

Chung-hee Park, who ruled from 1962 to 1979, was known to be a Buddhist, but he separated his religious conviction from the political reality because he especially considered major institutional religions as political resources. Similar to Rhee's administration, Park still pushed an evolutionary concept of religion under which world religions such as Buddhism and Christianity would be "developed religions," while Confucianism and folk religions were remains of pre-modern and anachronistic traditions. Religion had to become a cultural resource of economic development to be modernized as soon as possible. In this point of view, the state intervened actively in the religious as well as economic market. The Law of Hyangkyo (Confucian shrine) Properties and the Law of Management of Buddhist Properties in 1962 legalized the direct control of Confucian and Buddhist properties by the military regime (K. Yoo 2012, p. 73; Kamibeppu 2011, pp. 325-39). Hyangkyos and Buddhist temples were restricted severely in terms of the management and possession of their properties because the laws imposed complex administrational procedures and requirements on their economic activities. Protestantism and Catholicism faced no limitations in terms of taking advantage of their own economic resources, whereas the special laws seriously limited Buddhism and Confucianism in accessing various economic resources. The special laws remain even today.

\section{Conscientious Objectors in Korea Religious Market}

This brief review of the historical changes in religious regulations of Korea suggests that Korean religious market remains structurally unequal, depending on the religious preferences of political regimes. However, as the imprisonment of conscientious objectors belonging to Jehovah's Witnesses in Korea was declared by UHHRC in 1987 in violation of Article 18 of ICCPR, Korean religious market began to be under serious pressure from various international norms and organizations, including U.N. Human Rights Council, U.N. Human Rights Commission, European Court of Human Rights, IRFR of U.S., and so on. Given that the ruling institutions of administration, National Assembly, and judicial courts regarded conscientious objection as a purely domestic issue, they could not recognize a pluralistic nature of Korean religious market concerned with the issue of conscientious objection. Historically, both the rapid growth of Christianity and the decline of Confucianism in modern Korea resulted in a socio-cultural internalization of Christian dualistic worldview: the only god vs. idolatry, religion vs. superstition, good vs. evil, rationality vs. irrationality, modernity vs. feudality, etc. In this context, the governmental attitude toward conscientious objectors was compatible with the oligopolistic structure of Korean religious market controlled explicitly by Christianity and implicitly by Buddhism. The extreme pacifism as a religious doctrine, especially for Korean regimes 
and religious majorities, was stigmatized simply as a reflection of "irrational and fanatic" religiosity that could never be matched up with the post-war Korean political situation. In fact, the Ministry of Defense of Korea claimed continuously that conscientious objection eventually denies a nation-state ideology in which national security comes prior to religious faith. As the police physically oppressed shamanistic rituals (G. Kim 2007, p. 289), the ruling system of administration, National Assembly, and judicial courts did not hesitate to put conscientious objectors in jail because it could not integrate such practices into the ready-made category of "religion." They were even treated as "para-religions" or "pseudo-religions" in actual execution of religious laws, even though it is never possible to find a definition of religion in any Korean laws.

R.R. Holister and W.J. Holister brought some literature of Jehovah's Witnesses to Korea from Japan and also got the first Korean convert in 1914 (WOL 1930-2018). ${ }^{3}$ During the period of the Japanese imperialist wars in the 1930s in East Asia, similar to Jehovah's Witnesses in Japan and Taiwan, 38 conscientious objectors in Korea were first imprisoned as traitors in 1939 because they refused to take up arms for Japanese imperialist wars. Ironically, some documents issued by Korean government describe the deungdaesa (燈臺社) incident as part of Independence movement (Han 2004). After the Liberation from the Japanese in 1945, 12 believers composed the first Korean congregation of Jehovah's Witnesses in 1949 and became organizationally independent of their Japanese center. Don and Earlene Steele sent by the IBSA (International Bible Students Association) had 417 publishers in seven congregations in 1953 (WOL 1930-2018) ${ }^{4}$. As fundamentalist Protestants come to occupy a religious hegemony in Korea since the Liberation, the legal, social and political persecution of conscientious objectors has strengthened to justify morally the anti-communist ideology of military regimes and dictatorship. Since the Korean War, the Witnesses' uncompromising pacifism, refusal of blood transfusion, and door-to-door visit made them more isolated and sectarian from the established order of the post-war society. Both religious majorities and social elites did not hesitate to regard them as a dangerous and anti-social fanatic community. It seems that this social circumstance had a negative influence on the increase of their religious membership, even though they have about 99,000 members and 1300 congregations in 2011 (MCST 2011, p. 43). It was until the 1990s that international political organizations such as UN recognized Korean conscientious objectors' reality because both North and South Korea were allowed to join UN in 1991. Since then, Korean government had to report its situation of human rights regularly and simultaneously many international norms such as ICCPR came into effect equal to domestic laws. Based on the reports of Korean government, UNHRC continue to recommend to make conscientious objectors free and enact an alternative service for them in 1987, 1989, 1993, 1995, 1998 and 2004.

Meanwhile, the IRFR first included a brief description of conscientious objection in its 2004 issue. This impact of IRFR was very different from that of UNHRC recommendations because any decisions of the U.S. government based on the IRFR could determine the political, economic, and socio-cultural future of Korea, and in reality the U.S. embassy's deputy chief of mission discussed the problem of conscientious objectors with representatives of Jehovah's Witnesses and then asked Korean government to introduce an alternative service as soon as possible (IRFR 1998-2017) . $^{5}$ In response to this international pressure, the Ministry of National Defense of Korea "established a seventeen-member committee, made up of scholars, lawyers, journalists, religious leaders, civic activists, and military officials, to study ways to introduce and to establish the standards for such alternative service" (IRFR 1998-2017) ${ }^{6}$. Despite a negative conclusion of the committee against the introduction of alternative service, the administration announced the introduction an alternative

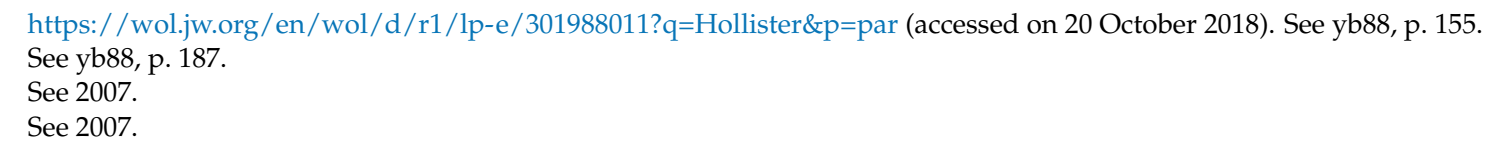


service for conscientious objectors on 18 September 2007, but cancelled its plan on 24 December 2008 after the launch of Myung Bak Lee's conservative regime.

About 1000 conscientious objectors, as Figure 1 shows, have been put in jail or judicial trial every year for the last ten years. It is reported that 20,000 young people were imprisoned due to conscientious objection so far, even if there is no official statistics issued by the government.

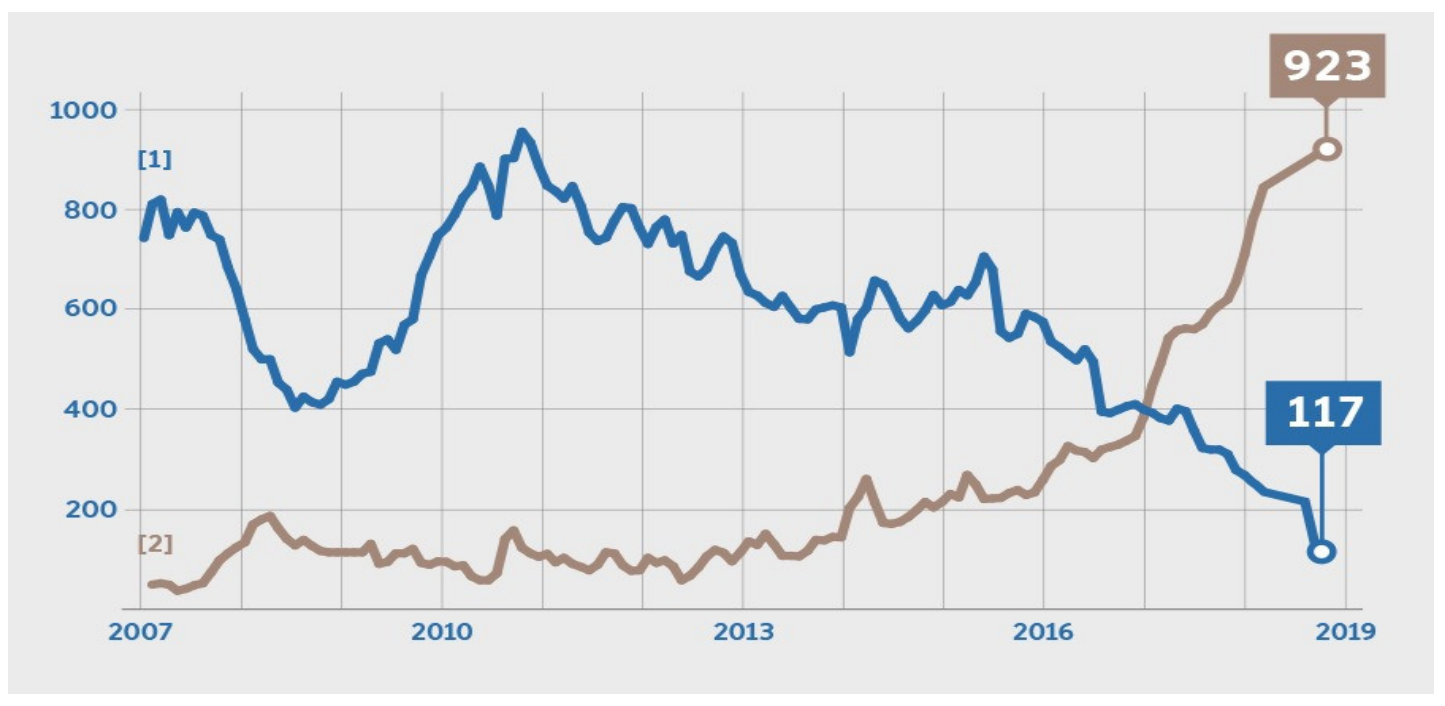

Figure 1. (1) Conscientious objectors imprisoned; and (2) pending cases of conscientious objectors. ${ }^{7}$

A groundbreaking change was made in 2004 by a local court of Seoul district (2002kodan3941), which declared conscientious objectors from Jehovah's Witnesses not guilty of violating military law. For the first time, the local court as a government institution regarded conscientious objection as a just reason to avoid the compulsory conscription. Since then, many local or high courts found religious conscientious objectors innocent of violating military law in totally 104 cases (Hankyoreh 23 August $2018)^{8}$. Nonetheless, both the Supreme Court and the Constitutional Court would not change their previous decisions and judgments which conscientious objectors are still violating the current positive law of Korea, while asking the National Assembly to revise the military law for introducing an alternative service (2004do2965; 2007do7941; 2002hunga1; 2008hunga22). Finally, the Constitutional Court of Korea declared on 28 June 2018 that the current military law should be revised to introduce an alternative service by 31 December 2019 because it violates conscientious objectors' human rights excessively (2011hunba379).

\section{From Sectarian Pacifism to Democratic Pluralism}

Although $92.5 \%$ of conscientious objectors worldwide are imprisoned in Korea (IRFR 1998-2017) ${ }^{9}$, almost all of them stick to a unique pacifism of Jehovah's Witnesses (JW) which can be interpreted as a sectarian choice made in a competitive religious market. From its beginning, Jehovah's Witnesses shared common roots with Seventh-Day Adventists (SDA) who believed in imminent eschatology derived from the Millerite movement in the 1840s. The two groups were not only initially very similar, but on other measures, such as international spread, growth rates, and total membership, have also remained remarkably alike (Lawson 1995, p. 353). Especially during World Wars I and II, sectarian conscientious objectors became well known for their rigid attitude toward conscription and military

\footnotetext{
https://www.jw.org/en/news/legal/by-region/south-korea/jehovahs-witnesses-in-prison (accessed on 10 September 2018). http:/ / www.hani.co.kr/arti/society/society_general/858916.html (accessed on 12 September 2018).

See 2013.
} 
service, which caused a very serious persecution of them across the world (Penton 1985; Wah 2002; Brock 2004; Stoltzfus 2013).

JW and SDA started to dispatch their missionaries into Korea in 1914 and 1904, respectively, and, during the period of Japanese rule, they were seriously persecuted by the Japanese colonialist government. It was not until the end of the Korean War that Jehovah's Witnesses and Seventh-Day Adventists did their missionary work intensively in Korea. In the 1960s, however, the Seven-Day Adventists allowed their members to decide freely on the issue of completing Korean military service in various ways, whereas Jehovah's Witnesses adhered to their unique pacifism and hence refused to compromise with secular authorities. Following the sectarian pacifism of the Mennonites, Brethren, and Quakers, who do not adopt the theory of just war as a traditional doctrine of Christianity, JW never gave up their resistance against the Korean conscription system, leading to about 20,000 conscientious objectors being put in jail thus far. The first federal conscription law of America allowed draft substitution upon payment of $\$ 300$ as early as 1863 and further Congress enacted the Selective Service Act in 1940 (Todd 1969, p. 1734), whereas Korean politicians and bureaucrats have been unwilling to introduce an alternative service.

Especially there is no cultural tradition of such sectarian pacifism in Korean history, even if a historical origin of conscientious objection can be traced back to Chinese Taoism, Buddhism, and Christian Reformation groups such as the Waldensians and Anabaptists (Kauffman 1989, p. 368). Rather, Korean Buddhism is well known for "Hokuk Bulkyo (Patriotic Buddhism)" because Korean Buddhists have never hesitated to participate in various wars and power struggles throughout all Korean history. Korean Protestantism has also played an important role in supporting or justifying Korean political regimes since its introduction in the 19th century. Korean people have never had a cultural experience to imagine the unique pacifism which transcends both national interest and security. After all, conscientious objectors of JW have failed to draw any political or emotional support even from mainstream Protestants as well as other religious majorities because they would not consider any cultural adaptation or compromise in contrast with the flexible strategy of SDA.

Obviously, conscientious objection is only one sectarian market strategy in terms of religious market theory (K. Yoo 2014, pp. 114-32). Especially, religious market theorists such as Rodney Stark, Roger Finke, and L. R. Iannaccone regard it as a rational strategy to exclude free riders out the sectarian organization (Iannaccone 1992; Stark and Iannaccone 1997; Stark and Finke 2002, p. 149). This strategy proved very effective for the growth of religious membership in the American cultural context, whether belonging to sectarian or church-like organizations (Finke and Iannaccone 1993; Iannaccone 1994; Finke 1997). According to Grim and Finke's research to verify the pluralism thesis of religious market theory, the increase of religious freedom tends to promote social peace, while the price of religious freedom being denied is social conflict (Grim and Finke 2011). In short, to legally protect a free and fair competition system between religious majorities and minorities now becomes one of the most important duties of democratic civil society in realizing religious freedom as human rights. Nonetheless, as the concept of conscientious objection based on a sectarian pacifism itself is still very foreign in the Korean civil society, the Supreme Court of Korea (SCK) has consistently confirmed the legitimacy of the current military service law which punishes conscientious objectors based on the sectarian pacifism of JW. A public poll conducted by the government in 2008 also showed that $68.1 \%$ of respondents objected to the introduction of an alternative service (Hankyoreh 21, 29 December 2008). ${ }^{10}$

It was the local courts across the country that began to protect the sectarian pacifism under the principle of pluralism, interpreting it as a basic operational rule of every democratic civil society. Since the 2004 decision of "not guilty", many local courts followed the judgment of acquittal, criticizing both legal interpretations and logical impropriety inherent in the previous SCK judgments. A local court in

10 http://h21.hani.co.kr/arti/COLUMN/32/24057.html (accessed on 11 September 2018). 
the city of Gwangju justified its decision of "not guilty", citing a judgment of the European Court of Human Right (Bayatyan vs. Armenia):

As democracy should guarantee a fair and reasonable treatment to the minorities instead of the abuse of the ruling power by the majorities, giving religious minorities the chance to serve the entire society implies not that it, as the government claims, causes an inequality and a unfair discrimination, but that it promotes the tolerance and harmony among religions and brings a stable pluralism. The European Court of Human Right explained the features of democracy as pluralism, tolerance, and broadmindedness.... The democratic majorities of a society should be responsible for realizing such democracy and social integration through protecting human rights of the minorities and making the protection of the socially weak institutionalized. If there are the majorities who neglect this duty in a society, the political system run by them is nothing but a nominal democracy because they are just the oppressive and numerical majorities. (2015no1181)

Given that mainstream Korean Protestants have shown a strong hatred against the word "pluralism" itself and both Korean politicians and scholars of religion have been unwilling to use it in a field of public discourse, this judicial interpretation of pluralism by the local courts was a significant and historical turning point on which one should acknowledge that pluralism is bound to function as an essential principle of the Korean civil society. Besides, a few social polls in 2016 showed an important change in the necessity of introducing an alternative service as soon as possible. A relative majority of respondents examined by Amnesty International and by the Bar Association in Seoul began to support the introduction of an alternative service by $70 \%$ and by $80.5 \%$, respectively, even if most of them answered that they cannot entirely accept a logical ground of conscientious objection. Thanks to these changes in public polls and many challenging decisions of local courts, the Constitutional Court of Korea (CCK) finally ordered on 28 June 2018 that the government and National Assembly introduce an alternative service in accordance with the higher idea of the Korean Constitution to protect conscientious freedom (2011hunba379).

The issue of conscientious objection in recent Korea concerns not only the socio-religious dimension, but also the construction of collective identity of a nation state (Pace 2011, p. 445). That makes Korean civil society rethink what pluralism is and how it works in the Korean context. The drastic decision of CCK is not a final solution, but only a new starting point for answering the self-reflective questions of Korean civil society. The integration of sectarian pacifism into a macro-level principle of pluralism was never touched in the 2018 CCK decision in contrast with many decisions of the local courts concerned with conscientious objectors. In addition to domestic conditions, the above-mentioned international factors such as IRFR and UNHRC make it much more complicated to understand the meaning of pluralism in a process of globalization because it is invoked in different ways such as a political ideology, a religious creed, and a basic principle of society, as the issue of conscientious objection in Korea shows clearly.

\section{Conclusions}

This paper focuses on the case of conscientious objection in the Korean socio-cultural context, which cannot be entirely comprehended by a religious concept of pluralism, particularly explaining how the concept of pluralism could be expanded through integrating a sectarian pacifism of JW into the entire civil society of Korea. Since Korea joined the U.N. in 1991, the criminal punishment and imprisonment of conscientious objectors in Korea has become a more complicated international issue because both U.S. and U.N. have intervened in this issue in the diplomatic, legal, or moral dimension. Although there was no sectarian and unique pacifism in the Korean cultural tradition, international powers forced Korean society to comprehend the non-Korean worldview in the name of human rights and pluralism. 
Except for conscientious objectors, Jehovah's Witnesses in Korea have enjoyed a high level of religious freedom for their missionary activities, including door-to-door visits, whereas their colleagues in European countries are in trouble legally or socially (Stark and Finke 2002, pp. 233-35; Richardson and Introvigne 2001). Unlike SDA, it is noteworthy that they chose conscientious objection as a market strategy in the Korean religious market. Indeed, religious market theorists tend to attribute their growth in American membership to this kind of religious strictness and conservativeness. However, they remain a sectarian minority isolated from the Korean civil society. The absolute majority of Korean people, including politicians and bureaucrats, do not agree to conscientious objectors in a moral, religious, or logical dimension.

The first judgment of acquittal by a local court in Seoul in 2004 has been followed by many decisions of the local or higher courts across the country. In parallel with the increasing religious diversity in contemporary Korea, the local courts tried to interpret the concept of pluralism in a much broader context of meaning than dealing with the matter of conscientious objection as a by-product of sectarian pacifism. That changed the matter of how Korean civil society should protect pluralism as a necessary element of democracy, and hence how pluralism in the Korean context can work in harmony with a global expansion of pluralism motivated by international powers.

Funding: This research was funded by the National Research Foundation of Korea funded by the Ministry of Education of the Republic of Korea (NRF-2016S1A2A2915833).

Conflicts of Interest: The author declares no conflict of interest.

\section{References}

Barker, Rachel. 1982. Conscientious, Government and War: Conscientious Objection in Great Britain 1939-1945. London and Boston: Routledge \& Kegan Paul.

Brock, Peter. 1968. Radical Pacifists in Antebellum America. Princeton: Princeton University Press.

Brock, Peter. 2004. These Strange Criminals: An Anthology of Prison Memoirs by Conscientious Objectors from the Great War to the Cold War. Toronto: University of Toronto Press.

Chin, Sang-Beom. 2006. Hankuksahoi Yangshimjuk Byungyeok Kuboo ei daehan Kukga wa Jongkyo ui Daeung (Confrontation of State and Religions against Conscientious Objectors in Contemporary Korean Society). Religion and Culture Studies 8: 191-217.

Cho, Hung-youn. 1988. Mukyo Sasangsa (History of Korean Shamanism). In Hankuk Jongkyo Sasangsa IV. Seoul: Yonsei University Press, pp. 221-333.

Finke, Roger. 1997. The Illusion of Shifting Demand: Supply-Side Interpretations of American Religious History. In Retelling U.S. Religious History. Edited by Thomas Tweed. Berkeley and London: University of California Press, pp. 108-24.

Finke, Roger, and Laurence R. Iannaccone. 1993. Supply-Side Explanation for Religious Change in America. The Annals 527: 27-39.

Flowers, Ronald B. 2002. To Defense the Constitution: Religion, Conscientious Objection, Naturalization, and the Supreme Court. Lanham: Scarecrow Press.

Grim, Brian J., and Roger Finke. 2011. The Price of Freedom Denied: Religious Persecution and Conflict in the Twentieth Century. New York: Cambridge University Press.

Han, Hong-Gu. 2004. 'yeohowa ui jeungin' apeseo pookeulupda (Shameful in Front of Jehovah's Witnesses). Hankyoreh 21, May 27. Available online: http://legacy.h21.hani.co.kr/section-021075000/2004/05/ 021075000200405270511062.html (accessed on 31 August 2018).

Iannaccone, Laurence R. 1992. Sacrifice and Stigma: Reducing Free-Riding in Cults, Communes, and Other Collectives. Journal of Political Economy 100: 271-92. [CrossRef]

Iannaccone, Laurence R. 1994. Why Strict Churches Are Strong. American Journal of Sociology 99: 1180-211. [CrossRef]

International Religious Freedom Report (IRFR). 1998-2017. Issued by U.S. Department of State. Available online: http:/ / www.state.gov/j/drl/irf/rpt/index.htm (accessed on 10 September 2018).

Kamibeppu, Masanobu. 2011. Keunhyundai Hanil Jongkyojungchaek Bikyoyeonku (A Comparative Study of Korean and Japanese Religious Policy in Pre-Modern and Modern Ear). Seoul: Jishik kwa Kyoyang. 
Kang, Incheol. 2003. Cheonjaing kwa Jongkyo (War and Religion). Osan: Hanshin University Press.

Kang, Incheol. 2005. Hankuksahoi wa Yangshimjuk Byungyeok Kuboo: Yeoksa wa TeuksungHistory (Korean Society and Conscientious Objection: History and Features). Religious and Cultural Studies 7: 103-41.

Kang, Seung-Sik. 2005. Mikuk Hunbupsang Jongkyo ui Jayoo (Freedom of Religion in the United States Constitution). The Korean Journal of American History 22: 223-57.

Kang, Dongu. 2006. Yeohowa ui Joungin ui Teukjing kwa Jeongae (The Characteristics and Development of 'Jehovah's Witness'). Korean Journal of Religious Studies 43: 45-69.

Kaplan, William. 1989. State and Salvation: The Jehovah's Witnesses and Their Fight for Civil Rights. Toronto: University of Toronto Press.

Kauffman, J. Howard. 1989. Dilemmas of Christian Pacifism within a Historic Peace Church. Sociological Analysis 49: 368-85. [CrossRef]

Kim, Dushik. 2002. Yangshimjuk Byungyeok Kubooj wa Kidokkyo (Conscientious Objection and Christianity). Human Rights and Justice 309: 140-53.

Kim, Suntaek. 2002. Hankunae Yangshimjuk Byungyeok Kubooja ei daehan Daechebokmoo Injungyeoboo ei kwanhan Ironjuk Shiljoungjuk Yeonku (A Theoretical and Empirical Research on Alternative Service of Conscientious Objector in Korea). Seoul: National Human Rights Commission of Korea.

Kim, Insoo. 2003. Hankukkidokyo Kyohoisa (History of Korean Christianity). Seoul: Korean Presbyterian Publishing Company.

Kim, Geumhwa. 2007. Bidankot Neomsae (Silk Flower called as Neomsae). Seoul: Sangkak ui Namu.

Lawson, Ronald. 1995. Sect-State Relations: Accounting for the Differing Trajectories of Seventh-Day Adventists and Jehovah's Witnesses. Sociology of Religion 56: 351-77. [CrossRef]

Ministry of Culture, Sports and Tourism of Korea (MCST). 2011. Hankukui Jongkyohyunwhang (The Index of Korean Reliigons); Seoul: Religious Affairs Office.

Moskos, Charles C., and John Whiteclay Chambers, II, eds. 1993. The New Conscientious Objection: From Sacred to Secular Resistance. New York: Oxford University Press.

Murayama, Jijun. 2005. Chosun ui Jeombok kua Yeiun (Divination and Prophecy in Chosun). Translated by Heekyung Kim. Seoul: Dongmunsun. First published 1993.

Pace, Enzo. 2011. The Socio-Cultural and Socio-Religious Origins of Human Rights. In The Oxford Handbook of the Sociology of Religion. Edited by Peter Clarke. New York: Oxford University Press, pp. 432-48.

Penton, M. James. 1985. Apocalypse Delayed: The Story of Jehovah's Witnesses. Toronto, Buffalo and London: University of Toronto Press.

Peters, Shawn F. 2000. Judging Jehovah's Witnesses-Religious Persecution and the Dawn of the Rights Revolution. Lawrence: University Press of Kansas.

Richardson, James. T. 1995. Legal Status of Minority Religions in the United States. Social Compass 42: $249-64$. [CrossRef]

Richardson, James. T. 2006. The Sociology of Religious Freedom: A Structural and Socio-Legal Analysis. Sociology of Religion 67: 271-94. [CrossRef]

Richardson, James T., and Massimo Introvigne. 2001. Brainwashing Theories in European Parliamentary and Administrative Reports on Cults and Sects. Journal for the Scientific Study of Religion 40: 143-68. [CrossRef]

Shin, Wonha. 2004. Yangshimjuk JipchongKuboo Uthukkae Boaya hana? (How should We see Conscientious Objection?). Ministry and Theology January: 241-45.

Sibley, Mulford Q. 1943. The Political Theories of Modern Religious Pacifism. The American Political Science Review 37: 439-54. [CrossRef]

Smith, Thomas W. 2001. Review: Religious Freedom as Foreign Policy Priority. International Studies Review 3: 152-56.

Stark, Rodney, and Roger Finke. 2002. Acts of Faith: Explaining the Human Side of Religion. Berkeley and London: University of California Press.

Stark, Rodney, and Laurence R. Iannaccone. 1997. Why the Jehovah's Witnesses Grow So Rapidly: A Theoretical Application. Journal of Contemporary Religion 12: 133-57. [CrossRef]

Statistics Korea. 2017. Population Census 2015. Available online: http://kosis.kr/eng/statisticsList/statisticsList_ 01List.jsp?vwcd=MT_ETITLE\&parentId=A (accessed on 2 September 2018).

Stevenson, Robert C. 1934. The Evolution of Pacifism. International Journal of Ethics 44: 437-51. [CrossRef]

Stoltzfus, Duane C. S. 2013. Pacifists in Chains: The Persecution of Hutterites during the Great War. Baltimore: Johns Hopkins University Press. 
Todd, Timothy G. 1969. Religious and Conscientious Objection. Stanford Law Review 21: 1734-49. [CrossRef]

Wah, Carolyn R. 2002. Jehovah's Witnesses and the Empire of the Sun: A Clash of Faith and Religion during World War II. Journal of Church and State 44: 45-72. [CrossRef]

Walters, LeRoy. 1973. A Historical Perspective on Selective Conscientious Objection. Journal of the American Academy of Religion 41: 201-11. [CrossRef]

Watchtower Online Library (WOL). 1930-2018. Yearbook of Jehovah's Witnesses. New York: Watch Tower Bible and Track Society. Available online: https:/ / wol.jw.org/en/wol/h/r1/lp-e (accessed on 20 October 2018).

Yoo, Kyung-Dong. 2005. Yangshimjuk Byungyeok Juboo wa Kidokkyo Sahoiyoonli (Conscientious Objection and Christian Social Ethics). Theology and World 52: 192-220.

Yoo, Kwangsuk. 2012. Applicability of Religious Economy Model (REM) to the Growth of Fortune-telling in Contemporary Korea. Ph.D. dissertation, The University of Ottawa, Ottawa, ON, Canada.

Yoo, Kwangsuk. 2014. Jongkyo Shichang ui Lihai (Understanding of Religious Market). Seoul: Dasan Publication.

Yoo, Kwangsuk. 2015. Numbers and Categorization of Korean Religious Minorities: A Comparison of Demographic Census and International Religious Databases. Discourse 201: 43-63.

Yoon, Yong-Bok. 2007. Yeohowa ui Joungin ui Yeoksa wa Teuksung (The History and Characteristic of 'Jehovah's Witnesses'). Korean Journal of Religious Studies 47: 289-313.

(c) 2018 by the author. Licensee MDPI, Basel, Switzerland. This article is an open access article distributed under the terms and conditions of the Creative Commons Attribution (CC BY) license (http:/ / creativecommons.org/licenses/by/4.0/). 